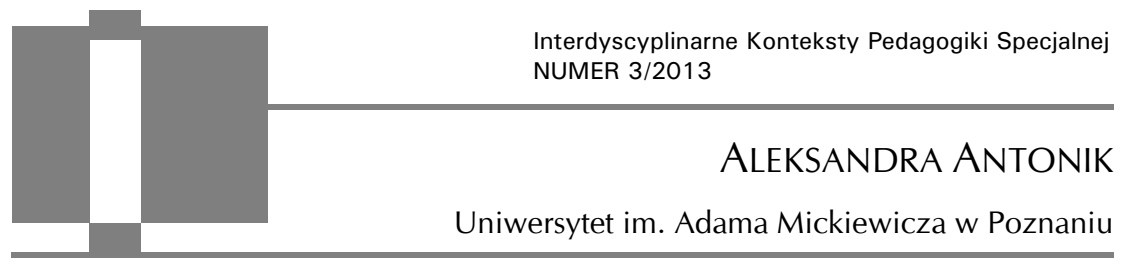

\title{
Edukacja włączająca w Norwegii
}

ABSTRACT: Antonik Aleksandra, Inclusive education in Norway [Edukacja włączająca w Norwegii]. Interdyscyplinarne Konteksty Pedagogiki Specjalnej, nr 3, Poznań 2013. Pp. 87-99. Adam Mickiewicz University Press. ISBN 978-83-232-2721-2. ISSN 2300-391X.

Norway belongs to the group of countries, where the idea of inclusive education, that is one of important UNESCO and European Commision's directions, is nearly fulfilled. Every child, whatever their special educational needs would be, has the right to attend a local school and to get there a proper help to reach their potential. Special pedagogy should serve the mainsteream schooling, which aim is to be as selfsufficient as it is possible when it comes to adapted educational forms and methods od teaching. Special education is the last option, when general ways of solvings the problem fail. The educational reform toward integration and inclusion of pupils with special eduacational needs was neither easy nor quick, so it is worth for other countries to use norwegian experiences in this field.

KEY WORDS: inclusion, Norwegian education, special pedagogy

„Włączanie rozpatrywać należy jako proces odpowiadania na różnorodność potrzeb wszystkich dzieci, młodzieży i dorosłych poprzez redukowanie, czy wręcz eliminowanie, wszelkich form dotykającego ich wykluczenia".

Kluczowe zasady stużące promocji jakości w edukacji włączającej, Europejska Agencja Rozwoju Edukacji Uczniów ze Specjalnymi Potrzebami, 2009 


\section{Wprowadzenie. Edukacja włączająca - definicja i przedmiot oddziaływań}

Termin „edukacja włączająca” lub stosowany zamiennie „edukacja inkluzywna” jest rozumiany jako długotrwały proces dążący do rozszerzania możliwości adaptacyjnych szkół w kontekście dostosowywania warunków do potrzeb uczniów niezależnie od tego, jak bardzo byłyby one zróżnicowane. Szkoła włączająca ma być odpowiedzialna za edukację uczniów z wszelakimi rodzajami niepełnosprawności, reprezentującymi różne środowiska społeczne. Cel, jaki przyświecał twórcom koncepcji, było to, aby każde dziecko miało równy dostęp do edukacji i możliwość uczęszczania do szkoły najbliżej swojego miejsca zamieszkania. W literaturze polskojęzycznej edukacja włączająca jest czasami utożsamiana z integracją, choć należy podkreślić, że nie są to równoznaczne pojęcia. W polskich warunkach jej realizacja oparta jest na tak zwanym modelu hamburskim, który polega na przyjmowaniu do klasy ogólnodostępnej określonej liczby uczniów z orzeczeniem o potrzebie kształcenia specjalnego i nadawanie jej w ten sposób statusu klasy integracyjnej (Gajdzica, 2008, s. 117). W odróżnieniu od pojęcia „integracja", które w praktyce okazuje się często sposobem asymilowania uczniów do zastanej rzeczywistości (Szumski, 2003, s. 71), koncepcja edukacji włączającej zakłada, że to nie uczeń ma być w procesie edukacji stroną, która musi zmienić się, aby sprostać zastanym wymaganiom, lecz szkoła, która powinna być na tyle elastyczna, by móc dostosować się do jego potrzeb związanych z niepełnosprawnością tak, by mógł w pełni wykorzystać swój potencjał i funkcjonować w swoim społecznym środowisku w sposób najbardziej dla niego optymalny (Nilsen, 2010, s. 480).

Szczególna uwaga w literaturze dotyczącej edukacji włączającej poświęcona jest uczniom o specjalnych potrzebach edukacyjnych jako grupie najbardziej narażonej na izolację i segregację społeczną. Grupa ta nie jest jednorodna i zaliczane są do niej zarówno osoby znajdujące się poniżej, jak i powyżej normy, przy czym odchylenie od normy występuje, kiedy rozwój ucznia odbiega od najczęstszego 
w populacji wzorca. Przedmiotem pedagogiki specjalnej jest jednak w głównej mierze edukacja i terapia jednostek mniej sprawnych ze względu na skutki, jakie dla funkcjonowania niesie z sobą ich niepełnosprawność (Dykcik, 2006, s. 13-15). W grupie uczniów o specjalnych potrzebach edukacyjnych uwzględniane są „wszystkie dzieci w wieku obowiązku szkolnego, które posiadają wyraźnie większe niż większość ich rówieśników trudności w uczeniu się, bez względu na to, czy źródłem tych trudności są uszkodzenia organiczne, czy też nie" (Szumski, 2006, s. 105). W niektórych publikacjach zawęża się znaczenie tego terminu i obejmuje się nim grupę osób z: zaburzeniami motorycznymi, uszkodzeniami narządu wzroku i słuchu, niepełnosprawnością intelektualną, parcjalnymi deficytami poznawczymi, zaburzeniami komunikacji językowej (w tym obcokrajowców), ADHD, zaburzeniami opozycyjno-buntowniczymi, zaburzeniami zachowania i emocji, autyzmem, przewlekle chore oraz z zaburzeniami karmienia i odżywiania (Andrzejewska, Sitarczyk, 2012, s. 3).

\section{Kształcenie uczniów o specjalnych potrzebach edukacyjnych w Norwegii - rys historyczny}

Początek historii norweskiego szkolnictwa powszechnego sięga pierwszej połowy XVIII w. Od samego początku charakteryzuje je tendencja do upowszechniania edukacji wśród wszystkich obywateli. "Szkoła dla wszystkich i każdego" to idea, jaką kierował się król duński Krystian VI, zlecając stworzenie powszechnego systemu szkolnictwa w Norwegii, będącej wówczas prowincją należącą do Królestwa Duńskiego. Ważny wpływ na rozwój szkolnictwa miała religia protestancka, zwłaszcza nurt luteranizmu zwany pietyzmem. Do założeń pietyzmu należały przede wszystkim modlitwa oraz studiowanie Biblii, co niosło z sobą potrzebę szerzenia edukacji, zwłaszcza umiejętności czytania, wśród najuboższych warstw społeczeństwa. Ponadto funkcjonującą w tamtym czasie ideologią poli- 
tyczną był kameralizm, czyli doktryna ekonomiczna uznająca za nadrzędny cel polityki gospodarczej państwa pełne wykorzystanie zasobów ludzkich i zdolności produkcyjnych w celu zwiększenia dochodów władcy. Powszechna edukacja stanowić miała, według ówczesnych władz, drogę do realizacji tych postulatów. Norwegia jest też pierwszym krajem, w którym wprowadzono elementy indywidualizacji procesu nauczania, zważając na to, że nie każdemu dziecku nauka przychodzi z jednakową łatwością i nie wszyscy uczą się $\mathrm{w}$ równym tempie. Zróżnicowanie $\mathrm{w}$ zakresie treści nauczania wprowadził Erik Pontoppidan, twórca pierwszego podręcznika dla norweskiej szkoły podstawowej. Zawierał on teksty z Biblii, których uczniowie uczyli się na pamięć. Zaznaczone były $\mathrm{w}$ nim treści obowiązkowe oraz takie, których uczniowie $\mathrm{z}$ problemami w uczeniu się nie musieli opanowywać. Pierwszym przykładem dostosowywania form nauczania do możliwości ucznia są dodatkowe domowe lekcje oferowane uczniom, którzy nie mogli opanować wymaganego materiału, w celu nadrobienia zaległości. Były one udzielane przez protestanckich księży odpowiedzialnych za edukację dzieci ze swoich parafii. Dzięki tak zindywidualizowanej formie nauczania wielu uczniów było w stanie przezwyciężyć swoje początkowe trudności i ograniczenia oraz osiągnąć sukces edukacyjny (Johansen, 2001, s. 133-137).

Sytuacja uczniów o specjalnych potrzebach edukacyjnych pogorszyła się z końcem XIX w., kiedy w roku 1889 wydany został akt określający kryteria korzystania z powszechnej edukacji. Na liście „niemile widzianych” znalazły się osoby, które ze względu na fizyczne lub poznawcze utrudnienia nie były w stanie nadążyć z przyswajaniem informacji za resztą klasy oraz dzieci niemogące sprostać wymaganiom szkolnej dyscypliny. W ten sposób pierwotnie inkluzywny system edukacji w Norwegii stał się segregacyjny. Pierwsza szkoła specjalna powstała w 1874 r., a w 1881 uchwalona została ustawa o edukacji specjalnej regulująca prawo do edukacji osób głuchych, niewidzących i osób z niepełnosprawnością intelektualną. Był to czas, kiedy zostało podważone prawo wszystkich obywateli do korzystania z powszechnej edukacji, nawet specjalnej. 
Miały do niej odtąd dostęp tylko osoby „wyuczalne”. Odpowiedzialność za opiekę i edukację uczniów „niewyuczalnych” została przeniesiona na Wydział Zdrowia i Spraw Publicznych, przez co osoby chore psychicznie lub z poważnymi niepełnosprawnościami trafiały pod skrzydła instytucji dobroczynnych, szpitali lub były izolowane w domach opieki (Tøssebro, 2003, s. 21-22). Z biegiem lat stosunek społeczeństw w całej Europie do tej grupy ludzi stawał się coraz bardziej wrogi, nacechowany lękiem i niechęcią. Początek XX w. to czas fascynacji teorią ewolucji i doboru naturalnego Darwina, który przyniósł ruch eugeniczny oraz próby eliminowania słabych, chorych jednostek za pomocą okrutnych, niehumanitarnych praktyk (na przykład sterylizacja lub izolowanie chorych w zamkniętych ośrodkach oddalonych od ludzkich siedzib). Choć praktyki te w Norwegii nie były zakorzenione tak silnie, jak w innych krajach europejskich, stanowią ciemną kartę $\mathrm{w}$ historii narodowej polityki wobec osób niepełnosprawnych (Johansen, 2001, s. 141-143). Na pierwszą połowę XX w. przypada rozkwit kształcenia segregacyjnego. Po wojnie priorytetem władz stało się odciążanie rodzin obarczonych koniecznością opieki nad niepełnosprawnymi dziećmi. Dążąc do całkowitej centralizacji systemu, utworzono kilka wielkich, wielospecjalistycznych instytucji kształcenia osób z niepełnosprawnościami. Znajdowały się przy nich internaty, więc dzieci z całego kraju mogły uczyć się z dala od swoich domów. $\mathrm{Z}$ czasem system ten stał się na tyle niewydolny, że nie był w stanie zaspokoić potrzeb całego kraju. By rozwiązać ten problem, w latach 50. XX w. odpowiedzialnością za organizowanie specjalnego kształcenia obarczono gminy i zaczęto tworzyć mniejsze, lokalne ośrodki (Tøssebro, 2003, s. 19-21). Ważnym dokumentem była uchwalona w 1967 r. „Biała karta”, zwana też „Aktem integracji”. W późniejszych latach była ona wielokrotnie nowelizowana i uzupełniana. Wprowadziła do systemu edukacji zasadę normalizacji i integracji idee, które były już wówczas popularne w krajach Europy Zachodniej. Istniał $\mathrm{w}$ niej zapis, by „dzięki zintensyfikowanym wysiłkom wyrwać więcej osób z wyizolowanego i biernego bytowania w instytucjach i umieścić je $\mathrm{w}$ bardziej społecznie funkcjonalnym oto- 
czeniu” („Biała karta”, s. 17, za: Tøssebro, 2003, s. 36). Uchwalenie "Aktu integracji” stanowiło początek nowej ery w edukacji norweskiej - edukacji włączającej. W latach 60. powstały pierwsze szkoły specjalne bez internatu. Górzyste ukształtowanie terenu oraz ogromny obszar nie sprzyjały tworzeniu placówek obsługujących większą liczbę miejscowości, dlatego z czasem nauczanie specjalne zaczęto organizować w lokalnych szkołach. W 1985 r. zamknięto ostatnią dużą instytucję zamieszkaną przez osoby z niepełnosprawnością. Druga połowa $\mathrm{XX}$ w. była w Norwegii początkiem integrowania systemu kształcenia specjalnego i ogólnokształcącego. W 1976 r. ujednolicono program nauczania we wszystkich szkołach, a paragrafy dotyczące kształcenia osób z niepełnosprawnością włączono do rozporządzenia dotyczącego edukacji ogólnodostępnej. Podkreślano w nim, że każde dziecko ma prawo do zindywidualizowanego podejścia i dostosowania form oraz metod nauczania do swoich potrzeb i możliwości. Narodowy program nauczania udoskonalany był podczas reform w latach 1987, 1997 oraz 2006 (Fasting, 2010, s. 181). Realizacja założeń przyjętych w rozporządzeniu nie była jednak ani prosta, ani szybka. Wciąż wielu nauczycieli i dyrektorów czerpało z wieloletniej praktyki segregacyjnej, przenosząc znane rozwiązania dotyczące kształcenia uczniów z niepełnosprawnością na grunt szkoły masowej. Ostatnia szkoła specjalna w Norwegii została zamknięta w 1992 r., choć nowy system, jakby broniąc się przez uczniami o specjalnych potrzebach edukacyjnych, przez długi jeszcze czas znajdował rozwiązania wyłączające dzieci z niepełnosprawnością z edukacji ogólnodostępnej w postaci klas specjalnych lub organizowania lekcji poza zwykłą klasą (Tøssebro, 2003, s. 42-43).

\section{Aktualne rozwiązania dotyczące edukacji włączającej w Norwegii}

Drogą do realizacji reformy z 1976 r. okazała się „edukacja przystosowana" (ang. adapted education), której najwierniejszym polskim odpowiednikiem jest „nauczanie zindywidualizowane”. Oznacza 
ono dostrzeganie różnic w rozwoju poszczególnych uczniów oraz respektowanie ich poprzez dostosowywanie treści, metod i sposobu organizacji procesu dydaktyczno-wychowawczego do indywidualnych właściwości każdej osoby. Celem nauczania zindywidualizowanego jest maksymalizowanie możliwości rozwoju każdego ucznia niezależnie od jego zdolności (Okoń, 1984, s. 104). Realizacja nauczania przystosowanego nie byłaby możliwa bez odpowiednich zmian w powszechnym programie nauczania (ang. core curriculum). Od początku jednolity dla każdej szkoły w Norwegii program traktowany był jako narzędzie do wyrównywania szans edukacyjnych dzięki temu, że każdy uczeń, bez względu na uwarunkowania społeczne czy geograficzne, miał dostęp do takiej samej edukacji i każdy kończąc szkołę, przynajmniej z założenia, posiadał taki sam zasób wiedzy. W latach 80., w obliczu rosnącego zróżnicowania etnicznego kraju w związku z napływem imigrantów, znaczenie tak pojętej równości zmieniło się. Uznano, że narzucanie jednolitych treści może stać się przyczyną dyskryminacji niektórych mniejszości. Reforma z 1987 r. podkreśliła, że treści nauczania powinny być dostosowane do lokalnych warunków oraz indywidualnych potrzeb każdej szkoły (Nilsen, 2010, s. 489). W 2006 r. po raz kolejny zreferowana została podstawa programowa, co miało doprowadzić do jeszcze większego wyrównania szans edukacyjnych wszystkich uczniów. Podkreślone zostały w niej podstawowe kompetencje, na jakie powinien zostać położony szczególny nacisk w toku nauczania każdego przedmiotu. Do tych kompetencji zalicza się: umiejętność wypowiadania się $\mathrm{w}$ mowie i w piśmie, czytanie ze zrozumieniem, liczenie oraz efektywne korzystanie z nowych mediów. Ponadto bardziej niż na zdobywanie wiedzy teoretycznej nacisk kładziony jest na nabywanie umiejętności społecznych (Hansen, 2005, s. 135). Odejście od ścisłego określania treści nauczania sprzyja większej elastyczności pracy nauczyciela oraz zwiększa możliwość indywidualnego dostosowania programu do warunków ucznia.

Pomimo że w Norwegii zlikwidowane zostały szkoły specjalne, uczniowie wciąż mają możliwość korzystania z edukacji specjalnej. Procedura kierowania ucznia do kształcenia specjalnego jest po- 
dobna jak w Polsce. W oficjalnych dokumentach podkreślane jest to, że zanim podjęte zostaną kroki kierujące ucznia przejawiającego trudności edukacyjne do nauczania specjalnego, szkoła, do której uczeń uczęszcza, jest zobligowana do wypróbowania wszelkich dostępnych środków w postaci edukacji zindywidualizowanej. Jeśli nie widać efektów, wówczas uczeń, za zgodą rodziców, jest kierowany do regionalnego centrum pomocy psychologiczno-pedagogicznej, gdzie jest diagnozowany pod kątem specjalnych potrzeb edukacyjnych. Następnie otrzymuje indywidualne zalecenia co do realizacji procesu edukacji w najbardziej odpowiadający jego potrzebom sposób. Na tej podstawie tworzony jest indywidualny program edukacyjno-terapeutyczny określający zakres treści, metod i form nauczania. Uczniowie o poważnych zaburzeniach otrzymują orzeczenie o potrzebie kształcenia specjalnego i zdarza się, że najbardziej optymalną formą nauczania jest klasa specjalna. Powinna być to jednak ostateczność, kiedy zawiodą inne dostępne zwykłemu nauczycielowi formy realizacji zaleceń. Dotyczy to jedynie osób, które nie są w stanie czerpać korzyści z nauki w zwykłej klasie ze względu na bardzo poważne zaburzenia poznawcze, sensoryczne lub komunikacyjne (The Education Act, s. 29-30). Działanie takie jest zgodne z tak zwaną drugą wykładnią zasady normalizacji, sformułowaną przez Wolfa Wolfensbergera, która mówi o tym, że wobec osób niepełnosprawnych należy stosować środki jak najbardziej zgodne z kulturowymi normami, aby rozwinąć u nich cechy i sposoby zachowań maksymalnie odpowiadające normom kulturowym (Szumski, 2006, s. 36). W roku szkolnym 2009/2010 ze specjalnej edukacji korzystało około 7\% uczniów, głównie w formie dodatkowych zajęć rewalidacyjnych i wyrównawczych. Jedynie 0,5\% uczniów korzystało z edukacji specjalnej w warunkach segregacyjnych, poza swoją szkołą rejonową (Fasting, 2010, s. 180). Polityka edukacyjna zmierza jednak do tego, aby przypadki takie były jak najrzadsze i aby maksymalnie ograniczyć zakres specjalnej pomocy w szkołach. Podkreśla się przy tym, że pedagogika specjalna w stosunku do nauczania ogólnodostępnego ma pełnić formę wspierającą oraz że nauczyciele klas ogólnodostępnych powinni 
ponosić główną odpowiedzialność za sukces edukacyjny uczniów o specjalnych potrzebach edukacyjnych. Jest to możliwe dzięki inwestowaniu energii i środków w nauczanie dostosowane do indywidualnych potrzeb każdego ucznia w ramach szkół ogólnodostępnych (Nilsen, 2010, s. 492-493). Wymaga to niewątpliwie ogromnych nakładów finansowych. Parlament norweski co roku na system edukacji wydaje 6,6\% dochodu krajowego brutto, przy czym średnia dla krajów strefy OECD wynosi 5,9\% (Norwegian Ministry of Education and Research, Education - from kindergarten to adult education, <http://www.regjeringen.no/upload/KD/Vedlegg/Veiledninger\% $20 \mathrm{og} \% 20$ brosjyrer/Education_in_Norway_f-4133e.pdf\#search=subjec tscurrycula> [dostęp: 26.10.2013]).

Koordynowaniem działań związanych z edukacją specjalną zajmuje się "norweski system wsparcia dla edukacji specjalnej” (norw. Statped). Kieruje on kilkoma multispecjalistycznymi placówkami zajmującymi się udzielaniem profesjonalnego wsparcia dla szkół oraz władz lokalnych z zakresu pracy z uczniami o specjalnych potrzebach edukacyjnych, takich jak: głębsza i głęboka niepełnosprawność intelektualna, uszkodzenia słuchu i wzroku, uszkodzenia mózgu oraz poważne zaburzenia komunikacyjne. W Norwegii w latach 80. niektóre szkoły specjalne zostały przekształcone w ośrodki specjalistyczne skupiające ekspertów wyspecjalizowanych w zakresie subdyscyplin pedagogiki specjalnej, takich jak tyflopedagogika i surdopedagogika. Planowane jest stworzenie narodowego centrum edukacji matematycznej, centrum nauki czytania oraz centrum edukacji wielokulturowej (Norwegian Ministry of Education and Research, Learning together. Report to Storting (white paper) summary 2010-2011, <http://www.european-agency.org/country-information /norway/national-overview/Special-Needs-Education-Norway.pdf> [dostęp: 26.10.2013]). Ponadto, w każdym większym mieście funkcjonują edukacyjne centra konsultacyjno-doradcze, w których pracują psycholodzy, pedagodzy, pedagodzy specjalni, pracownicy socjalni i inni specjaliści. Takie centra oferują szkolenia dla nauczycieli oraz doraźne wsparcie w zakresie metod i form edukacji uczniów $\mathrm{z}$ niepełnosprawnością. Celem działalności Statped jest stworzenie 
merytorycznego zaplecza, z którego mogłyby korzystać szkoły w celu zaadaptowania warunków nauczania dla uczniów o specyficznych potrzebach wynikających z niepełnosprawności. Centra te kontrolują też sposób realizacji zaleceń dotyczących nauczania uczniów o specjalnych potrzebach edukacyjnych (The Education Act, s. 31). Zatem, likwidując szkoły specjalne, nie chodziło o to, by zupełnie wyeliminować pedagogikę specjalną - owszem uznano ją za bardzo ważny element budowania systemu inkluzywnego. Starano się jednak nie dopuścić do tego, aby nauczyciele zrzucali odpowiedzialność za rozwiązywanie problemów uczniów o specjalnych potrzebach edukacyjnych na pedagogów specjalnych, lecz aby sami, z merytorycznym wsparciem osób wyspecjalizowanych w tym obszarze, odnajdywali nowe, twórcze rozwiązania. Ponadto celem ograniczania liczby pedagogów specjalnych w szkołach ogólnodostępnych było również to, by dawni nauczyciele placówek specjalnych nie przenosili starych metod i form pracy do nowej, włączającej szkoły (Nilsen, 2010, s. 488). Problem utrzymywania aktywnej równowagi pomiędzy nauczaniem ogólnym a specjalnym jest przedmiotem ciągłej dyskusji w środowiskach dążących do poprawy jakości kształcenia w Norwegii.

Analizując sposób realizowania edukacji uczniów o specjalnych potrzebach edukacyjnych w Norwegii, można odnieść wrażenie, że nauczyciel szkoły ogólnodostępnej powinien posiadać bardzo szeroką, specjalistyczną wiedzę z zakresu pedagogiki specjalnej, aby poradzić sobie z nauczaniem klasy złożonej z uczniów o bardzo zróżnicowanych potrzebach i możliwościach. Okazuje się jednak, że program kształcenia nauczycieli nie jest w jakiś szczególny sposób zorientowany na przekazywanie wiedzy o różnych niepełnosprawnościach. W programie studiów obowiązkowy jest blok „pedagogika i umiejętności związane z pracą z uczniem”, jednak nie ma przedmiotów ukierunkowanych na metodykę pracy $\mathrm{z}$ osobami $\mathrm{z}$ konkretnymi rodzajami niepełnosprawności (The teacher - the role and the education, <http://www.regjeringen.no/upload/KD/Ved legg/stortingsmeldinger/Teacher_Education_Factsheet.pdf> [dostęp: 26.10.2013]). W kilku ośrodkach akademickich w kraju można stu- 
diować pedagogikę uczniów o specjalnych potrzebach edukacyjnych, jednak nie jest to zbyt popularny kierunek ze względu na ograniczoną liczbę miejsc pracy dla pedagogów specjalnych. Bardziej dostępnym rozwiązaniem jest roczny kurs podyplomowy. W kształceniu nauczycieli większy nacisk kładziony jest na kształtowanie kompetencji dydaktycznych i metodologicznych w zakresie nauczanego przedmiotu. Nauczyciel powinien wiedzieć, w jaki sposób rozwijać podstawowe kompetencje oraz jak indywidualizować proces nauczania. Powinien posiadać wiedzę na temat różnorodnych metod i form po to, aby móc różnicować podejście do dzieci. Ponadto wysoko cenionymi kompetencjami nauczycieli są: umiejętność pracy w zespole, zdolności komunikacyjne, wrażliwość na potrzeby dziecka, gotowość do rozszerzania swoich kwalifikacji oraz refleksyjność $\mathrm{w}$ stosunku do swojej pracy (Teacher training in Norway, <http://www.european-agency.org/country-information/ norway/norwegian-files/Teacher-Training-in-Norway.pdf> [dostęp: 26.10.2013]). Jeśli nauczyciel spotyka się z problemem, z którym nie może sobie poradzić za pomocą dostępnych mu środków, może liczyć na pomoc i wsparcie ze strony specjalistów zatrudnionych w centrach pomocy psychologiczno-pedagogicznej.

\section{Podsumowanie}

Norwegia to kraj, w którym tradycje segregacyjne nie mają głębokich korzeni. Wysoko cenioną wartością jest równość wszystkich ludzi (Aase, 2005, s. 13-17). Dominująca religia protestancka sprzyjała upowszechnieniu szkolnictwa wśród wszystkich warstw społecznych. Ze względu na specyficzne walory geograficzne Norwegia nie ma feudalnej historii, która w wielu europejskich krajach zostawiła piętno w postaci klas społecznych oraz trudnego do zmiany przekonania o wyższości niektórych ludzi nad innymi. Ponadto ogromna powierzchnia kraju w połączeniu z niewielkim zaludnieniem sprzyja tworzeniu się samowystarczalnych społeczności lokalnych, gdzie nie jest opłacalne izolowanie pojedynczych, odbie- 
gających od normy jednostek w stworzonych specjalnie dla nich instytucjach. Segregacyjny system nauczania nie był w tym przypadku pożądany ani opłacalny (Fasting, 2010, s. 180). Wymienione czynniki powodują, że Norwegia stała się dobrym gruntem dla rozwoju edukacji włączającej. Jej sukces uzależniony jest od zdolności do uznania i zaakceptowania różnorodności występującej wśród uczniów. Dostosowanie warunków nauczania do potrzeb i możliwości dzieci o specjalnych potrzebach edukacyjnych wymaga chęci oraz dużego zaangażowania ze strony szkoły, a przede wszystkim nauczyciela. Nie powinien on zostać z tym wyzwaniem pozostawiony sam. Zadaniem pedagogów specjalnych jest wspieranie nauczycieli w tej pracy, przy czym powinni oni mieć na uwadze, że zbytnia ingerencja oraz stosowanie specjalnych środków tam, gdzie nie jest to absolutnie konieczne, może spowodować stygmatyzację, a w konsekwencji dyskryminację ucznia odbiegającego od arbitralnie przyjętej „normy”. Norwegia uznawana jest za kraj, w którym idea edukacji włączającej jest bliska urzeczywistnienia. Mimo wszystko implementacja tego systemu nie jest wcale zadaniem łatwym. Z przedstawionej analizy wynika, że nie stało się to w sposób samoistny, lecz wymagało zarówno radykalnych przedsięwzięć w aspekcie legislacyjnym, jak i przewartościowania sposobu myślenia o edukacji. Warto jednak podejmować taki wysiłek, aby szkoły mogły wreszcie stać się dostępne dla wszystkich dzieci.

\section{Bibliografia}

AASE A., In search of Norwegian Values, [w:] E. Maagerø, B. Simonsen (red.), Norway: society and culture, Portal, Indiana 2005.

ANDRZEJEWSKA J., SITARCZYK M., Specjalne potrzeby edukacyjne w przestrzeni systemu oświaty. Teoretyczne i metodologiczne założenia programu: praca z uczniem ze specjalnymi potrzebami edukacyjnymi - wsparcie kadry nauczycielskiej, Akademia Humanistyczno-Ekonomiczna w Łodzi, Lublin 2012.

DYКСІK W., Wprowadzenie do pedagogiki specjalnej jako nauki, [w:] W. Dykcik (red.), Pedagogika specjalna, Wyd. Nauk. UAM, Poznań 2006.

FASTING R.B., Inclusion through the concept of adopted education: a review of Norwegian challenges, "Special Education” 2010, 1(22). 
GAJDZICA Z., Organizacja kształcenia integracyjnego w Polsce na tle wybranych rozwiązań europejskich, [w:] Z. Gajdzica, J. Rottermund, A. Klinik (red.), Uczeń niepetnosprawny i jego nauczyciel w przestrzeni szkoły, Oficyna Wydawnicza „Impuls”, Kraków 2008.

HANSEN A., Education in Norway - equality, nature and knowledge, [w:] E. Maagerø, B. Simonsen (red.), Norway: society and culture, Portal, Indiana 2005.

JOHANSEN B., Introduction to the history of special needs education towards inclusion. A Norwegian and european context, [w:] H. Johnsen, M.D. Skjørten (red.), Education - Special Needs Education: An Introduction, Univ. Press, Oslo 2001.

NILSEN S., Moving towards an educational policy for inclusion? Main reform stages in the development of Norwegian unitary school system, "International Journal of Inclusive Education" 2010, nr 5.

OKOŃ W., Stownik pedagogiczny, PWN, Warszawa 1984.

SZUMSKI G., Integracyjne ksztatcenie niepetnosprawnych, Wyd. Nauk. PWN, Warszawa 2006.

TØSSEBRO J., Stosunek do osób niepetnosprawnych intelektualnie oraz rodzaj świadczonych im ustug we wspótczesnej Norwegii, [w:] E. Zakrzewska-Manterys, A. Gustavsson (red.), Społeczny obraz upośledzenia, Wyd. Instytutu Filozofii i Socjologii PAN, Warszawa 2003.

Netografia

Norwegian Ministry of Education and Research, Education - from kindergarten to adult education, <http://www.regjeringen.no/upload/KD/Vedlegg/Veilednin ger\%20og\%20brosjyrer/Education_in_Norway_f-4133e.pdf\#search=subjectscur ricula>, [dostęp: 26.10.2013].

Norwegian Ministry of Education and Research, The Education Act, Act of 17 July 1998 no. 61 relating to Primary and Secondary Education and Training. Brzmienie od 1 sierpnia 2013, <http://www.regjeringen.no/upload/KD/Vedlegg/Grunnskole /dokumenter/EducationAct_with_amendments_entered2013.pdf>, [dostęp: 26.10. 2013].

Norwegian Ministry of Education and Research, The national support system - special education expertise for the whole of Norway, [w:] Learning together. Report to Storting (white paper) summary 2010-2011, <http://www.european-agency.org/countryinformation/norway/national-overview/Special-Needs-Education-Norway.pdf>, [dostęp: 26.10.2013].

Norwegian Ministry of Education and Research, The teacher - the role and the education. Report to the Storting No. 11 (2008-2009), <http:/ / www.regjeringen.no/ upload/KD/Vedlegg/stortingsmeldinger/Teacher_Education_Factsheet.pdf>, [dostęp: 26.10.2013].

The European Agency for Development in Special Needs Education, Teacher training in Norway, <http://www.european-agency.org/country-information/Norway /norwegian-files/Teacher-Training-in-Norway.pdf>, [dostęp: 26.10.2013]. 